\title{
Antioxidant films from mango kernel components
}

\author{
Pedro E.F. Melo ${ }^{a}$, Ana Priscila M. Silva ${ }^{a}$, Francisco P. Marques ${ }^{b}$, Paulo R.V. Ribeiro ${ }^{c}$, \\ Men de sá M. Souza Filho ${ }^{c}$, Edy S. Brito ${ }^{c}$, Janice R. Lima ${ }^{\mathrm{d}}$, Henriette M.C. Azeredo ${ }^{\mathrm{c}, \mathrm{e}, *}$ \\ ${ }^{a}$ Federal University of Ceara, Department of Chemical Engineering, Campus Pici, Bl. 709, 60455-760, Fortaleza, CE, Brazil \\ ${ }^{\mathrm{b}}$ Federal University of Ceara, Department of Organic and Inorganic Chemistry, Campus Pici, Bl. 940, 60440-900, Fortaleza, CE, Brazil \\ ${ }^{\mathrm{c}}$ Embrapa Agroindústria Tropical, R. Dra. Sara Mesquita, 2270, Fortaleza, CE, 60511-110, Brazil \\ ${ }^{\mathrm{d}}$ Embrapa Agroindústria de Alimentos, Av. das Américas, 29501, Guaratiba, Rio de Janeiro, RJ, 23020-470, Brazil \\ ${ }^{\mathrm{e}}$ Embrapa Instrumentação, R. 15 de Novembro, 1452, Caixa Postal 741, São Carlos, SP, CEP 13560-970, Brazil
}

\section{A R T I C L E I N F O}

\section{Keywords:}

Biopolymers

Edible films

Biorefinery

Active food packaging

\begin{abstract}
A B S T R A C T
Different compounds were sequentially extracted from mango seed kernels, namely, mango kernel fat (MKF), a phenolic extract (MKPE), and starch (MKS), with yields of about 11\%, 17\%, and 39\% respectively. The main fatty acids in MKF were oleic and stearic. Gallic acid and its derivatives were the predominant phenolics in MKPE. Glycerol-plasticized films were prepared with different weight proportions of MKS (80-100\%), MKF (0-20\%), and MKPE (0-20\%). The presence of fats and phenolics presented plasticizing effects on the starch films, although their elongation has sharply decreased when the MKF content increased from 10 to $20 \%$, probably because of the high saturation of MKF. MKPE was more effective than MKF in decreasing water vapor permeability. Moreover, the phenolics imparted the films with active (antioxidant and UV absorbing) properties, although they also decreased the visible light transparency of films.
\end{abstract}

\section{Introduction}

In the 20th century, fossil resources were established as primary feedstocks for the chemical industry. However, in the last few decades, their depletion has raised a red flag for the necessity of an alternative approach to the conventional petroleum-based refinery. Biorefinery has then emerged as a new paradigm for sustainable development, based on obtaining value-added products from renewable feedstocks (biomass or food waste) by using biological and/or chemical technologies (Esposito \& Antonietti, 2015). Those trends are within a context of global efforts to reduce wastes and to improve the economics of processing industries.

Mango is the third most exported tropical fruit, with an estimated 1.9 million tonnes exported in 2018. The mango production worldwide has been 46.5 million metric tons in 2016 (Statista, 2018), 'Tommy Atkins' being the predominant variety (UNCTAD, 2016). Some recent studies have presented mango co-products (seeds and/or peels) as promising feedstocks for biorefineries (Arora, Banerjee, Vijayaraghavan, MacFarlane, \& Patti, 2018; Banerjee et al., 2018; Jahurul et al., 2015a; Matharu, Houghton, Lucas-Torres, \& Moreno, 2016). The mango seed (stone) comprises about $22 \mathrm{wt} \%$ of Tommy Atkins mangoes, containing a kernel ( $13 \mathrm{wt} \%$ of fruit weight) and a shell (Plant-O-Gram, 2015). While the main component of the kernel is starch (Kaur, Singh, Sandhu, \& Guraya, 2004), other components are present, such as a fat whose composition and properties are similar to those of cocoa butter (Jahurul et al., 2017), making it potentially interesting for the confectionery industry, and phenolics (Adilah, Jamilah, \& Hanani, 2018a).

Starch is one of the most used polysaccharides for production of biodegradable and edible films for food packaging. However, like all polysaccharides, starch is predominantly hydrophilic, which makes it a poor barrier to water vapor. The addition of lipid components has been reported to decrease water vapor permeability of starch-based films (Rodrigues et al., 2014; Sartori \& Menegalli, 2016) and coatings (PérezGallardo et al., 2015).

Apart from barrier and tensile properties, which are important from the perspective of passively protecting the food, some active (such as antimicrobial or antioxidant) properties are also interesting for extending food stability, being sometimes incorporated into edible films and coatings. Antioxidant properties are particularly interesting for oxidizable foods. Advantages are expected from adding additives such as antioxidants to food packaging instead of the food itself, namely, the lower required amount of the active compounds, and controlled release to food (Mellinas et al., 2015).

Lipid oxidation, which mainly affects foods rich in unsaturated

\footnotetext{
* Corresponding author. Embrapa Instrumentação, R. XV de Novembro, 1452, São Carlos, SP, 13560-970, Brazil.

E-mail address: henriette.azeredo@embrapa.br (H.M.C. Azeredo).
} 
lipids, is a radical chain reaction consisting of initiation, propagation, and termination, resulting in production of free radicals and volatile compounds that produce off-flavors (oxidative rancidity). When it comes to antioxidants, they are categorized into primary and secondary. Primary antioxidants (usually known simply as antioxidants) break the chain reaction by donating a hydrogen atom to radicals, while the secondary ones act by different other mechanisms, one of them being absorption of ultraviolet (UV) light, which catalyzes oxidation reactions. Some previous studies have reported phenolic compounds to act as primary antioxidants (Dou, Li, Zhang, Chu, \& Hou, 2018; Fabra, Falcó, Randazzo, Sánchez, \& López-Rubio, 2018; Piñeros-Hernandez, Medina-Jaramillo, López-Córdoba, \& Goyanes, 2017) and/or UV absorber (Dou et al., 2018; Piñeros-Hernandez et al., 2017) in biopoplymer films. Active antioxidant coatings have been also proven effective to extend stability of beef (Barbosa-Pereira, Aurrekoetxea, Angulo, Paseiro-Losada, \& Cruz, 2014), walnuts (Kang, Kim, You, Lacroix, \& Han, 2013; Sabaghi, Maghsoudlou, Khomeiri, \& Ziaiifar, 2015), pine nuts (Haq, Alam, \& Hasnain, 2013), and peanuts (Wambura, Yang, \& Mwakatage, 2011).

Some previous studies have described the development of films from mango by-products. Some of them have used mango kernel starch as a film matrix by itself (Nawab, Alam, Haq, \& Hasnain, 2016) or combined to guar and xanthan gums (Nawab, Alam, Haq, Lufti, \& Hasnain, 2017). Our group has worked on mango kernel starch films reinforced with starch nanocrystals (Oliveira et al., 2018) or combinations of starch and cellulose nanocrystals (Silva et al., 2019). Mango kernel extract (Adilah et al., 2018a) and mango peel extracts (Adilah, Jamilah, Noranizan, \& Hanani, 2018b) have also been used for films, but the film matrices were not mango-based. This was the first study to combine three chemical fractions extracted from mango kernels to produce active films, namely, mango kernel starch (MKS) as a matrix, added with mango kernel fat (MKF), and phenolic extract (MKPE). MKF was added to confer some hydrophobic character to the films (improving their barrier to water vapor), and the MKPE, to provide films with active (primary antioxidant and UV absorber) properties.

\section{Materials and methods}

\subsection{Production of mango kernel flour}

Mango stones were manually separated from cut and depulped mangoes (Mangifera indica L. cv. 'Tommy Atkins') which had been purchased at a local market (CEASA, Maracanaú, CE, Brazil) at ripening stage 3 (GTZ, 1992), washed and sanitized with chlorinated water $(0.2 \mathrm{~g} / \mathrm{kg})$ for $15 \mathrm{~min}$.

The mango stones were decorticated, and the kernels were immersed in water to avoid browning reactions. After all stones were decorticated, the kernels were removed from water, ground with a cutter (R 201 Ultra E, Roubot-Coupe, Vincennes, France) for $5 \mathrm{~min}$ at $1500 \mathrm{rpm}$, and dried in an oven (NE 5043, Nova Ética, Vargem Grande do Sul, Brazil) for $48 \mathrm{~h}$ at $60 \pm 2{ }^{\circ} \mathrm{C}$, The dried ground kernels were then milled (Fritsch Pulverisette 19, Fritsch, Idar Oberstein, Germany, equipped with a $0.2-\mathrm{mm}$ sieve).

The mango kernel flour was analyzed for ashes by incineration in a muffle furnace (Q318M24, Quimis, Diadema, Brazil) at $600{ }^{\circ} \mathrm{C}$, and also for proteins (Kjeldahl method), total starch (method 043/IV, IAL, 2008), and lipids (AOAC method 920.39). All analyses were made in triplicate.

\subsection{Sequential extraction and characterization of fractions}

\subsubsection{Mango kernel fat (MKF)}

MKF extraction was carried out in a Soxhlet apparatus, each batch having $50 \mathrm{~g}$ mango kernel flour and $350 \mathrm{~mL}$ hexane, for $16 \mathrm{~h}$. The hexane was then removed from the fat/hexane mixture using a rotary evaporator (Büchi R-215, Büchi, Flawil, Switzerland) at $65^{\circ} \mathrm{C}$ and
$500 \mathrm{mbar}$, and the fatty acid profile of the resulting MKF was determined.

The methyl esters were prepared by direct esterification, according to Hartman and Lago (1973), and analyzed in a Varian GC CP3380 gas chromatograph (Varian Chromatograph Systems, Walnut Creek, USA) equipped with a flame ionization detector and an SP-2560 capillary column $(100 \mathrm{~m} \times 0.25 \mathrm{~mm}$ diameter $\times 0.02 \mathrm{~mm}$ thickness; Supelco, Bellefonte, USA). The injection and detector temperatures were $220^{\circ} \mathrm{C}$ and $230{ }^{\circ} \mathrm{C}$, respectively. The carrier gas was $\mathrm{H}_{2}\left(1.5 \mathrm{~mL} \mathrm{~min}^{-1}\right)$. The column temperature program was set as follows: $80^{\circ} \mathrm{C}$ for $1 \mathrm{~min}$, up to $180^{\circ} \mathrm{C}$ at $11^{\circ} \mathrm{C} \cdot \mathrm{min}^{-1}$, then up to $220^{\circ} \mathrm{C}$ at $5{ }^{\circ} \mathrm{C} \cdot \mathrm{min}^{-1}$, and then maintained for $9 \mathrm{~min}$ at $220^{\circ} \mathrm{C}$. The fatty acids were identified by comparing their retention times with those of methyl ester standards (Supelco, Bellefonte, USA), and quantified by area normalization.

\subsubsection{Mango kernel phenolic extract (MKPE)}

The defatted flour was left in a convection oven (JP 101, ACB Labor, São Paulo, Brazil) at $45^{\circ} \mathrm{C}$ for $24 \mathrm{~h}$ for removal of the remaining hexane. The phenolics were extracted in Soxhlet with methanol (each batch with $50 \mathrm{~g}$ mango kernel flour and $350 \mathrm{~mL}$ methanol) for $24 \mathrm{~h}$. The raw methanolic extract was concentrated in rotary evaporator at $50{ }^{\circ} \mathrm{C}$ and $200 \mathrm{mbar}$, and filtered through $0.28 \mu \mathrm{m}$ filter paper. The remaining solvent was removed from the filtrate by drying at $65^{\circ} \mathrm{C}$ for $48 \mathrm{~h}$ in a static oven (Q31614, Quimis, Diadema, Brazil).

Total phenolics were determined on MKPE by a modified FolinCiocalteu method (Singleton \& Rossi, 1965). Aliquots of extracts $(0.1-0.5 \mathrm{~mL})$ were taken into test tubes and completed to $0.5 \mathrm{~mL}$ with a $10 \%$ ethanol solution. The Folin-Ciocalteu reagent $(0.5 \mathrm{~mL})$ was added to each tube and, after $3 \mathrm{~min}$, also a sodium carbonate $20 \%$ solution $(0.5 \mathrm{~mL})$. The volumes were completed to $5 \mathrm{~mL}$, the tubes were vortexed for $30 \mathrm{~s}$ then left to rest for $90 \mathrm{~min}$. The absorbances at $725 \mathrm{~nm}$ were measured (Varian Cary $50 \mathrm{UV}$-vis spectrophotometer, Varian, Palo Alto, USA). A gallic acid stock solution at $0.012 \mathrm{mg} / \mathrm{mL}$ (in ethanol $10 \%)$ was prepared, from which seven different solutions were prepared for the standard curve (with 0.001, 0.003, 0.005, 0.007, 0.010, 0.011 , and $0.012 \mathrm{mg} / \mathrm{mL}$ ). The results were expressed as GAE (gallic acid equivalents) in $\mathrm{g} / 100 \mathrm{~g}$, using the standard curve equation: $\mathrm{y}=94.778 \mathrm{x}+0.043, \mathrm{R}^{2}=0.997$.

The identification of the compounds present in MKPE was carried out by Ultra-performance liquid chromatography coupled with quadrupole time-of-flight mass spectrometry operating in $M S^{\mathrm{E}}$ mode (UPLCQTOF $/ \mathrm{MS}^{\mathrm{E}}$ ), by using an Acquity UPLC system (Waters, Milford, USA) with an electrospray ionization (ESI) source. The eluent was a mixture of A $(0.1 \%$ formic acid in water) and B $(0.1 \%$ formic acid in acetonitrile) at a flow rate of $0.4 \mathrm{~mL} / \mathrm{min}$. The gradient varied linearly from $2 \%$ to $95 \%$ B (v/v) from 0 to 15.0 min, was held constant at $100 \%$ B from 15.1 to $17.0 \mathrm{~min}$, and concluded with a final wash and re-equilibration with $2 \%$ B from 17.1 to $19.1 \mathrm{~min}$. A Waters Acquity UPLC BEH column $(150 \times 2.1 \mathrm{~mm}, 1.7 \mu \mathrm{m})$ with a flow rate of $0.4 \mathrm{~mL} \mathrm{~min}^{-1} \mathrm{kept}$ at $40^{\circ} \mathrm{C}$ was used. The sample injection volume was $5 \mu \mathrm{L}$. Mass spectra were recorded in negative mode in a mass range of $100-1200 \mathrm{Da}$. The instrument settings were: source temperature at $120^{\circ} \mathrm{C}$; desolvation gas temperature at $350^{\circ} \mathrm{C}$; desolvation gas flow at $500 \mathrm{~L} \mathrm{~h}^{-1}$; extract cone voltage of $0.5 \mathrm{~V}$; capillary voltage of 2.6 and $3.2 \mathrm{kV}$. Leucine enkephalin was used as lock mass standard. A SPE clean-up was performed on the MKPE extract. The MKPE solution was passed through a C18 cartridge and rinsed with $3 \mathrm{~mL}$ of water, and the phenolics were eluted with $6 \mathrm{~mL}$ of a $90 \%(\mathrm{v} / \mathrm{v})$ methanol solution. The eluate was then filtered through $0.22 \mu \mathrm{m}$ PTFE membranes and injected into the system. The acquisition and analysis of data were controlled using Waters MassLynx 4.1 software (Waters, Milford, USA). The compounds were putatively identified based on their exact mass and comparison with previously published data. The term putative was employed for compound annotation since MS and/or MS/MS data are not enough for an unequivocal identification (Sumner et al., 2007). 


\subsubsection{Mango kernel starch (MKS)}

The flour residue was dried at $45^{\circ} \mathrm{C}$ for $24 \mathrm{~h}$ in a convection oven (JP 101, ACB Labor), and submitted to starch isolation, adapted from the method described by Oliveira et al. (2018). The residue was added with distilled water $(500 \mathrm{~mL}$ for each $60 \mathrm{~g}$ of flour residue), homogenized in Ultra-Turrax T50 (Ika, Staufen, Germany) at $4000 \mathrm{rpm}$ for $15 \mathrm{~min}$, and filtered through a 60 -mesh polyamide sieve. The residue was washed through the sieve with more distilled water $(1 \mathrm{~L}$ for each $60 \mathrm{~g}$ of initial flour residue). The resulting slurry (about $1500 \mathrm{~mL}$ ) was added with $3 \mathrm{~L}$ of a $0.2 \%(\mathrm{~m} / \mathrm{v}) \mathrm{NaOH}$ solution and stirred $(500 \mathrm{rpm}$, $2 \mathrm{~h}, 25^{\circ} \mathrm{C}$ ). It was then allowed to settle for $15 \mathrm{~min}$. The decanted starch was then centrifuged in a High-Speed Refrigerated Centrifuge CR22GIII (Hitachi, Tokyo, Japan) at $24,000 \mathrm{~g}$ at $4{ }^{\circ} \mathrm{C}$ for $20 \mathrm{~min}$. The starch precipitate was collected, repeatedly washed in distilled water (precipitate/water weight ratio, 1:2), stirred (200 rpm, $5 \mathrm{~min}$ ), and centrifuged, until the starch suspension reached $\mathrm{pH}$ 7. The suspension was vacuum filtered through $28 \mu \mathrm{m}$-pore filter paper, then the starchy residue was allowed to dry in an oven at $40^{\circ} \mathrm{C}$ for $24 \mathrm{~h}$, and ground with an analytical mill (Ika A11, Staufen, Germany). The starchy residue was then bleached. First, it was immersed into a $0.2 \%(\mathrm{~m} / \mathrm{v}) \mathrm{NaOH}$ solution at $40{ }^{\circ} \mathrm{C}\left(20 \mathrm{~mL}\right.$ for each gram of starch residue), then a $\mathrm{H}_{2} \mathrm{O}_{2} 35 \mathrm{vol} \%$ solution was added ( $6 \mathrm{~mL}$ for each gram of starch residue), and the suspension was stirred for $1 \mathrm{~h}$ at $250 \mathrm{rpm}$. Another equal volume of $\mathrm{H}_{2} \mathrm{O}_{2} 35$ vol\% solution was added, and the stirring was kept for more $30 \mathrm{~min}$. The suspension was then centrifuged at $24,000 \mathrm{~g}$ at $4{ }^{\circ} \mathrm{C}$ for $20 \mathrm{~min}$, and washed in distilled water until $\mathrm{pH} 7$. The bleached starch suspension was vacuum filtered through $28 \mu \mathrm{m}$-pore filter paper, the residue was allowed to dry in an oven $\left(40^{\circ} \mathrm{C}, 24 \mathrm{~h}\right)$, and ground with the analytical mill.

The starch was analyzed for ashes and proteins (same methods as for mango kernel flour), in triplicate. The amylose content was measured according to the standard method ISO 6647-1 (2015), also in triplicate.

The yield of each fraction (MKF, MKP, and MKS) was expressed as dry weight (g) per $100 \mathrm{~g}$ (dry weight) of the initial mango kernel flour.

\subsection{Formation of active emulsion films}

Ten films were produced, according to simplex centroid mixture design with three components: MKS, MKF, and MKPE (Fig. 1). Each film was made from $15 \mathrm{~g}$ of a MKS/MKF/MKPE mixture (in proportions as in Fig. 1) in $215 \mathrm{~mL}$ of distilled water. The MKS was gelatinized in distilled water $\left(95^{\circ} \mathrm{C}\right.$, for $30 \mathrm{~min}$, under stirring), then the other components were added - namely, glycerol ( $25 \mathrm{wt} \%$ of MKS), MKF, polyoxyethylene sorbitan monooleate (Tween 80 , at $5 \mathrm{wt} \%$ of MKF), sorbitane monooleate (Span 80, at $15 \mathrm{wt} \%$ of MKF), and MKPE - and kept under stirring at $60^{\circ} \mathrm{C}$ for $15 \mathrm{~min}$. The emulsion was sonicated with a probe ultrasound processor (DES500, Unique, São Paulo, Brazil) for $5 \mathrm{~min}$ at $90 \mathrm{~W}$, and homogenized with an Ultra Turrax T25 (Ika, Staufen, Germany) at $10,000 \mathrm{rpm}$ for $15 \mathrm{~min}$, keeping the temperature at $55^{\circ} \mathrm{C}$ with a heating plate. Air bubbles were removed under vacuum (using an MA 057/1 vacuum pump, Marconi, Piracicaba, SP, Brazil), and the films were cast on Mylar substrates on leveled glass plates for a thickness of $1.5 \mathrm{~mm}$. The films were allowed to dry at room conditions $\left(23^{\circ} \mathrm{C}, 50 \%\right.$ $\mathrm{RH}, 48 \mathrm{~h}$ ). After being detached from the Mylar surfaces, films were cut into test samples and conditioned for $48 \mathrm{~h}$ under controlled temperature and relative humidity $\left(23 \pm 1{ }^{\circ} \mathrm{C}, 50 \pm 3 \% \mathrm{RH}\right)$ before analyses.

\subsection{Film characterization}

\subsubsection{Tensile tests}

Tensile properties of $125 \mathrm{~mm} \times 12.5 \mathrm{~mm}$ film strips (with ten replicates) were measured according to D882-12 (ASTM, 2012), using a Universal Testing Machine (Emic DL-3000, São José dos Pinhais, Brazil) with a load cell of $100 \mathrm{~N}$, initial grip separation of $100 \mathrm{~mm}$, and crosshead speed of $50 \mathrm{~mm} / \mathrm{min}$. Before the test, the sample thicknesses were measured with an Akrom KR1250 coating thickness tester (Akrom, São Leopoldo, RS, Brazil) to the nearest $1 \mu \mathrm{m}$.

\subsubsection{Water vapor permeability (WVP)}

The water vapor permeability (WVP) determination, with eight replicates, was based on the method E96/E96M-16 (ASTM, 2016) at $24^{\circ} \mathrm{C}$, using $2 \mathrm{~mL}$ distilled water inside permeation cells (inner diameter, $24 \mathrm{~mm}$; height, $10 \mathrm{~mm}$ ) and silica gel as desiccant, in an Arsec DCV040 desiccator with air circulation (Arsec, Vargem Grande Paulista, SP, Brazil). At least eight measurements were made within $24 \mathrm{~h}$. Before the test, the sample thicknesses were measured with an Akrom KR1250 coating thickness tester (Akrom, São Leopoldo, RS, Brazil) to the nearest $1 \mu \mathrm{m}$.

\subsubsection{Antioxidant activity via DPPH inhibition}

The antioxidant activity of the films was evaluated by using 2,2diphenyl-1-picrylhydrazyl (DPPH) free radical scavenging assay inhibition assay was applied to evaluate the free radical scavenging activity of films, by a method adapted from that described by Byun, Kim, and Whiteside (2010), in triplicate. Approximately $900 \mathrm{mg}$ of each film was placed in a flask coated with aluminum foil containing $18 \mathrm{~mL}$ of methanol, and stirred at $150 \mathrm{rpm}$ for $3 \mathrm{~h}$ at room temperature $\left(25^{\circ} \mathrm{C}\right)$ in an orbital shaker (MA-410, Marconi, Piracicaba, Brazil). The supernatant was then analyzed for DPPH radical scavenging activity, by adding $2 \mathrm{~mL}$ of methanolic solution of DPPH $(0.06 \mathrm{mM})$ to $1000 \mu \mathrm{L}$ of the supernatant. The control was $1000 \mu \mathrm{L}$ of methanol without the film.
(A) MKS

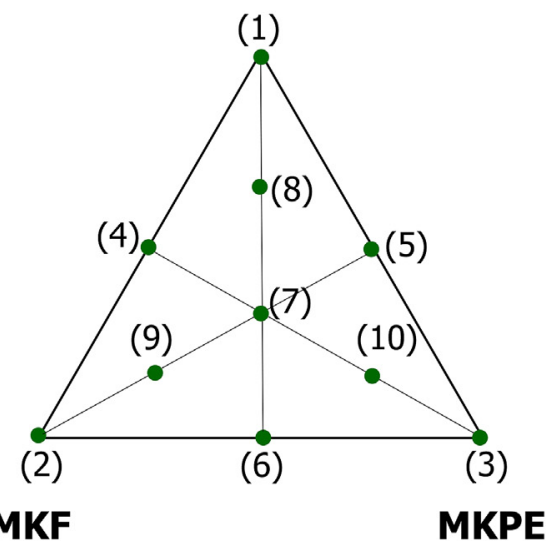

MKPE
(B)

\begin{tabular}{ccccccc}
\hline \multirow{2}{*}{ Runs } & \multicolumn{3}{c}{ Components } & \multicolumn{3}{c}{ Pseudo-components } \\
& $\mathbf{X}_{\mathbf{1}}$ & $\mathbf{X}_{\mathbf{2}}$ & $\mathbf{X}_{3}$ & $\mathbf{X}_{1}$ & $\mathbf{X}_{2}$ & $\mathbf{X}_{3}$ \\
\hline 1 & 1 & 0 & 0 & 1 & 0 & 0 \\
2 & 0.8 & 0.2 & 0 & 0 & 1 & 0 \\
3 & 0.8 & 0 & 0.2 & 0 & 0 & 1 \\
4 & 0.9 & 0.1 & 0 & 0.5 & 0.5 & 0 \\
5 & 0.9 & 0 & 0.1 & 0.5 & 0 & 0.5 \\
6 & 0.8 & 0.1 & 0.1 & 0 & 0.5 & 0.5 \\
7 & 0.867 & 0.067 & 0.067 & 0.33 & 0.33 & 0.33 \\
8 & 0.933 & 0.033 & 0.033 & 0.67 & 0.17 & 0.17 \\
9 & 0.833 & 0.133 & 0.033 & 0.17 & 0.67 & 0.17 \\
10 & 0.833 & 0.033 & 0.133 & 0.17 & 0.17 & 0.67 \\
\hline
\end{tabular}

Fig. 1. Simplex centroid design. (A) Graphical representation of the experimental runs. (B) Conditions (as components and pseudo-components) of each run. 
The mixture was vortexed for $30 \mathrm{~s}$ and left for $30 \mathrm{~min}$ in the dark, at $25^{\circ} \mathrm{C}$. The remaining DPPH was determined by the absorbance at $517 \mathrm{~nm}$ using a Varian Cary $50 \mathrm{UV}-$ Vis spectrophotometer (Varian, Santa Clara, USA). The antioxidant activity (AA) was defined as:

$A A(\%)=100 *\left(1-\frac{A_{\text {sample }}}{A_{\text {control }}}\right)$,

where $\mathrm{A}_{\text {sample }}$ and $\mathrm{A}_{\text {control }}$ are the absorbances of the sample solution and the DPPH solution (control) respectively. The antioxidant activity was expressed as \% DPPH radical scavenging activity/100 mg of film.

\subsubsection{Optical properties}

The opacity to visible and UV light was determined (in quadruplicate) by a modification of the method described by Irissin-Mangata et al. (2001). Film strips $(1 \mathrm{~cm} \times 5 \mathrm{~cm})$ were placed within the internal side of a spectrophotometer cell (Varian Cary 50 UV-Vis, Agilent Technologies, Santa Clara, CA, USA), perpendicularly to the light beam, and the absorbance spectrum $(200-800 \mathrm{~nm}$ ) was recorded. Opacity (to visible light) was defined as the area under the recorded curve between 400 and $800 \mathrm{~nm}$ (estimated by the linear trapezoidal rule) and expressed as absorbance units $\times$ nanometers (wavelength) per millimeter (film thickness) (A. nm.mm-1). UV absorbance was determined by the same method, but considering the curve between 200 and $400 \mathrm{~nm}$.

\subsubsection{Fourier transform infrared (FTIR)}

Fourier-transform infrared spectroscopy (FTIR) spectra were recorded in a Frontier FTIR/NIR spectrometer (PerkinElmer, Waltham, MA, USA) with an attenuated total reflectance (ATR) accessory with zinc selenide ( $\mathrm{ZnSe}$ ) crystal surface, using the arithmetic average of four scans in the wavenumber range from 4000 to $550 \mathrm{~cm}^{-1}$, with a resolution of $4 \mathrm{~cm}^{-1}$.

\subsubsection{Scanning electron microscopy (SEM)}

The scanning electronic microscopy (SEM) micrographs of the films (air-contact surfaces) were taken using a QUANTA FEG-FEI $450 \mathrm{mi}$ croscope. The samples were mounted on an aluminum stub using carbon-coated double sided adhesive tape, coated with a $20 \mathrm{~nm}$-thick gold layer by using a Quorum QT150ES metallizer, and examined using an accelerating voltage of $10 \mathrm{kV}$ and a magnification of 3,000 times.

\subsubsection{Statistical analyses}

Results of tensile tests, WVP, antioxidant activity, and optical properties were analyzed using the software Minitab ${ }^{\circ}$ (Minitab Inc., State College, PA, USA). The model adjustment was made in terms of pseudo-components.

\section{Results and discussion}

\subsection{Characterization of mango kernel components}

The determinations on mango kernel flour and resulting fractions are presented at Table 1 . The yield of MKF was very close to the lipid content of the flour, indicating a high lipid recovery. Similarly, almost all the phenolics were recovered from the flour. On the other hand, the starch recovery was about $60 \%$, suggesting that the starch extraction method should be improved.

MKF has presented stearic, oleic, and linoleic acid contents similar to those reported for cocoa butter, although its palmitic acid content was much lower, as previously reported (Sonwai, Kaphueakngam, \& Flood, 2014). That is why some studies have attempted to obtain cocoa butter equivalents from blending $\mathrm{MKF}$ and palm oil mid-fraction (Sonwai et al., 2014) or palm stearin (Jahurul et al., 2015b).

The amylose content of MKS was similar to that of corn starch (Dai, Qiu, Xiong, \& Sun, 2015; Sifentes-Nieves et al., 2019), which is high enough to form strong films (since the mostly linear amylose is more
Table 1

Determinations on components from mango kernels (on a dry basis).

\begin{tabular}{|c|c|c|}
\hline Component/fraction & Determinations & Average $( \pm S D)$ \\
\hline \multirow[t]{5}{*}{ Mango kernel flour } & Ashes (wt\%) & $2.5 \pm 0.3$ \\
\hline & Proteins (wt\%) & $5.6 \pm 0.5$ \\
\hline & Lipids (wt\%) & $11.2 \pm 1.4$ \\
\hline & Total starch (wt $\%)$ & $64.8 \pm 5.3$ \\
\hline & Total phenolics (mg GAE/100 g) & $57.8 \pm 4.8$ \\
\hline \multirow[t]{7}{*}{ MKF } & Yield $(w t \%)^{\mathrm{a}}$ & $10.9 \pm 1.8$ \\
\hline & Palmitic acid (16:0) (wt\%) & 6.6 \\
\hline & Stearic acid (18:0) (wt\%) & 36.3 \\
\hline & Oleic acid $(18: 1, n-9)(w t \%)$ & 41.5 \\
\hline & Linoleic acid (18:2, n-6) (wt\%) & 6.2 \\
\hline & Arachidic acid (20:0) (wt\%) & 1.8 \\
\hline & $\begin{array}{l}\text { Cis-13,16-docosadienoic acid (22:2, n- } \\
\text { 6) (wt } \%)\end{array}$ & 2.4 \\
\hline \multirow[t]{2}{*}{ MKPE } & Yield $(w t \%)^{\mathrm{a}}$ & $16.7 \pm 2.3$ \\
\hline & Total phenolics (mg GAE/100 g) & $340 \pm 26$ \\
\hline \multirow[t]{4}{*}{ MKS } & Yield $(w t \%)^{\mathrm{a}}$ & $39.0 \pm 3.7$ \\
\hline & Ashes (wt\%) & $0.27 \pm 0.02$ \\
\hline & Proteins (wt\%) & $0.79 \pm 0.06$ \\
\hline & Amylose (wt\%) & $30.5 \pm 3.1$ \\
\hline
\end{tabular}

a Yields on mango kernel flour.

able to form hydrogen bonds than the branched amylopectin).

Fig. 2 shows the chromatogram of MKPE, and Table 2 shows the assigned compounds. The main compounds tentatively identified were gallic acid and its derivatives, including ellagic acid. Those compounds were previously reported in mango kernels, being pentagalloyl-O-glucose the major compound independently of the mango cultivar (Barreto et al., 2008; Dorta, González, Lobo, Sánchez-Moreno, \& de Ancos, 2014).

\subsection{Characterization of films}

Table 3 presents the properties of all films and the corresponding estimated regression coefficients (in pseudo-components), while Fig. 3 shows the graphical representation of the significant models (i.e. all except elongation and antioxidant activity).

Linear models were the most suitable for strength, modulus, opacity, and UV absorption, while quadratic models were the most adequate for the other responses.

The presence of MKF and MKPE made the films less strong and rigid, suggesting that they presented plasticizing effects on the starch films. Actually, lipid components other than MKF have been reported in previous studies to impair tensile strength and modulus, since they hinder the formation of intermolecular bonds between chains of the matrix, promoting discontinuities that reduce the cohesion in the polymer network (Kowalczyk et al., 2016; Rocca-Smith et al., 2016). Plasticizing effects have also been reported from phenolic compounds and/or extracts (Alkan \& Yemenicioğlu, 2016; Jaramillo, Gutiérrez, Goyanes, Bernal, \& Famá, 2016), and are ascribed to the increased free space within the film matrix (Choi, Lee, Chang, Lacroix, \& Han, 2018).

Although a significant model for elongation was not fitted, some observations may be drawn from the average responses. Films containing at least $6.7 \%$ MKPE tended to present higher elongation, corroborating the plasticizing effects of phenolics. MKF, on the other hand, seemed to present a strong plasticizing effect when added at $10 \%$ (film \#4), but the elongation sharply decreased when the MKF content was raised to $20 \mathrm{wt} \%$ (film \#2), which is probably ascribed to the high saturated fatty acid (SFA) content of MKF (Table 1). SFAs are solid at room temperature, forming a rigid dispersed phase which decreases film elongation, as reported previously (Fernández, Apodaca, Cebrián, Villarán, \& Maté, 2007; Kowalczyk et al., 2016).

Surprisingly, MKF presented a less remarkable effect on reducing the film WVP than MKPE (Fig. 3, Table 3). Actually, when film \#2 (with the highest MKF content) is compared to film \#1 (without MKF), the 


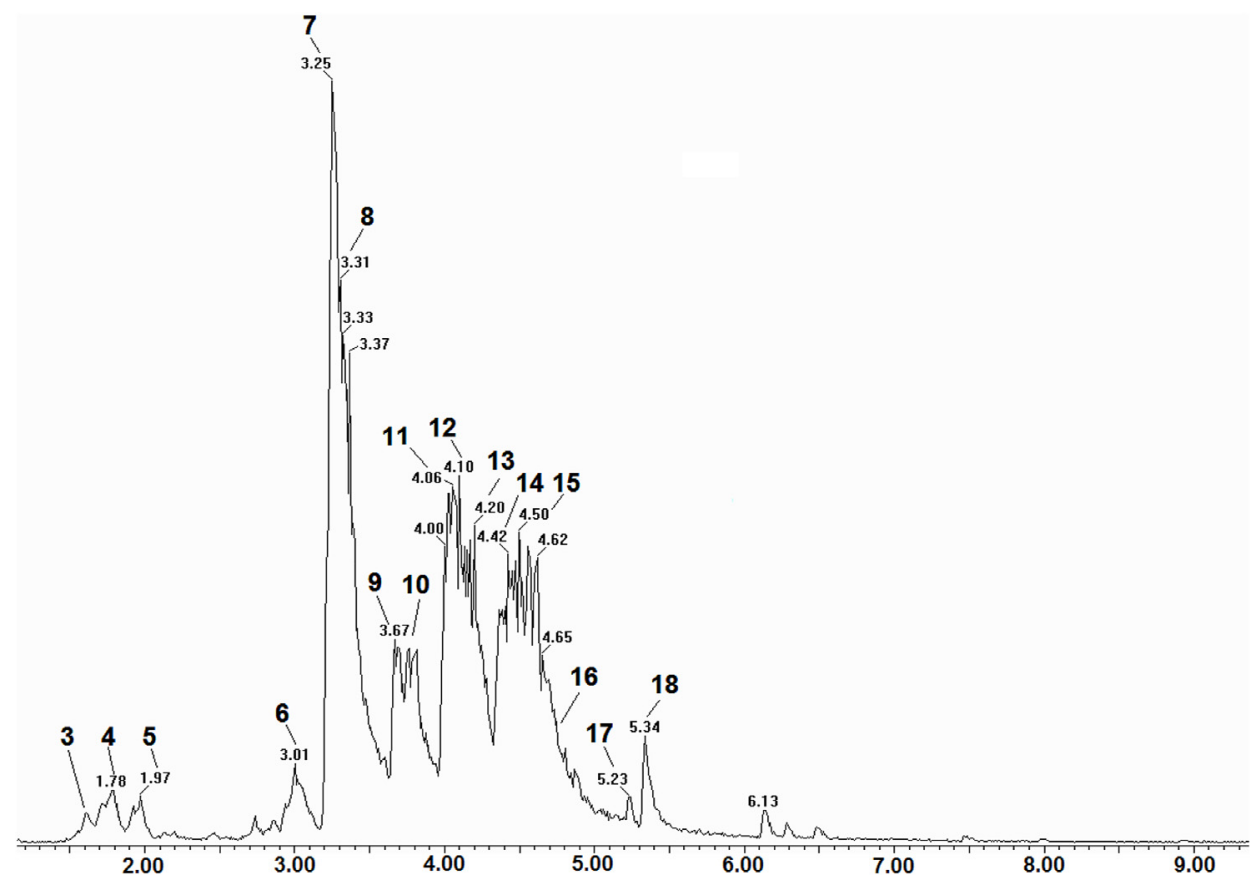

Fig. 2. Chromatogram of mango kernel phenolic extract (MKPE) and characterization of phenolic compounds using UPLC-ESI-MS/MS.

Table 2

Compounds tentatively identified in MKPE using UPLC-ESI-MS.

\begin{tabular}{|c|c|c|c|c|c|c|c|}
\hline Peak & {$[\mathrm{M}-\mathrm{H}]^{-} m / z(\exp )$} & {$[\mathrm{M}-\mathrm{H}]^{-} m / z$ (calc) } & Product ions (MS/MS) & Empirical formula & Error (ppm) & Proposed compound & Ref. \\
\hline 2 & 493.1198 & 493.1193 & $331.06,313.05,169.01,125.03$ & $\mathrm{C}_{19} \mathrm{H}_{25} \mathrm{O}_{15}$ & 1.0 & Galloyl-sucrose & a \\
\hline 3 & 331.0672 & 331.0665 & $169.01,125.02$ & $\mathrm{C}_{13} \mathrm{H}_{15} \mathrm{O}_{10}$ & 2.1 & Galloyl hexoside & a \\
\hline 5 & 493.1187 & 493.1193 & 169.01 & $\mathrm{C}_{19} \mathrm{H}_{25} \mathrm{O}_{15}$ & -1.2 & Galloyl diglucoside & a \\
\hline 6 & 635.0895 & 635.0884 & $483.08,465.07,169.01,125.02$ & $\mathrm{C}_{27} \mathrm{H}_{23} \mathrm{O}_{18}$ & 1.7 & Trigalloyl hexoside & $\mathrm{a}$ \\
\hline 7 & 183.0296 & 183.0293 & 124.01 & $\mathrm{C}_{8} \mathrm{H}_{7} \mathrm{O}_{5}$ & 1.6 & Methylgallate & $\mathrm{a}, \mathrm{b}$ \\
\hline 8 & 421.0776 & 421.0771 & $331.05,301.03$ & $\mathrm{C}_{19} \mathrm{H}_{17} \mathrm{O}_{11}$ & 1.2 & Mangiferin $^{\mathrm{a}}$ & $\mathrm{a}, \mathrm{b}$ \\
\hline 11 & 787.0992 & 787.0994 & $635.09,169.01$ & $\mathrm{C}_{34} \mathrm{H}_{27} \mathrm{O}_{22}$ & -0.3 & Tetra-O-galloyl-glucoside isomer & $\mathrm{a}, \mathrm{b}$ \\
\hline 12 & 787.0999 & 787.0994 & $635.09,169.01$ & $\mathrm{C}_{34} \mathrm{H}_{27} \mathrm{O}_{22}$ & 0.6 & Tetra-O-galloyl-glucoside isomer & $\mathrm{a}, \mathrm{b}$ \\
\hline 13 & 300.9989 & 300.9984 & - & $\mathrm{C}_{14} \mathrm{H}_{5} \mathrm{O}_{8}$ & 1.7 & Ellagic acid ${ }^{\mathrm{a}}$ & $\mathrm{a}, \mathrm{b}$ \\
\hline 14 & 939.1112 & 939.1104 & 169.01 & $\mathrm{C}_{41} \mathrm{H}_{31} \mathrm{O}_{26}$ & 0.9 & Pentagalloyl-O-glucose isomer & $\mathrm{a}, \mathrm{b}$ \\
\hline 15 & 939.1115 & 939.1104 & 169.01 & $\mathrm{C}_{41} \mathrm{H}_{31} \mathrm{O}_{26}$ & 1.2 & Pentagalloyl-O-glucose isomer & $\mathrm{a}, \mathrm{b}$ \\
\hline 16 & 335.0392 & 335.0403 & $183.02,168.01,124.01$ & $\mathrm{C}_{15} \mathrm{H}_{11} \mathrm{O}_{9}$ & -3.3 & Methyl digallate & $b, c$ \\
\hline 17 & 939.1133 & 939.1104 & 169.01 & $\mathrm{C}_{41} \mathrm{H}_{31} \mathrm{O}_{26}$ & 3.1 & Pentagalloyl-O-glucose isomer & $\mathrm{a}, \mathrm{b}$ \\
\hline
\end{tabular}

a Identification using standard; (a) Gómez-Caravaca, López-Cobo, Verardo, Segura-Carretero, \& Fernández-Gutiérrez (2016); (b) Barreto et al. (2008); (c) Li, Kuang, Chen, and Zeng (2016).

difference in WVP was not even significant (Table 3). Fats usually are very effective in decreasing WVP of films, because of their hydrophobic character (Rodrigues et al., 2014; Tongnuanchan, Benjakul, Prodpran, \& Nilsuwan, 2015). However, the relative rigidity of MKF (because of its high SFA content) may have reduced the interconnection of the matrix network (Xiao et al., 2016), promoting disruptions to the film cohesion, which are observed in film \#2 (Fig. 4). On the other hand, the phenolics promoted a remarkable decrease in WVP, the film with the highest MKPE content (\#3) presenting a WVP 40\% lower than the control film (\#1). This may be ascribed to the slight hydrophobicity of the phenolics and/or to hydrogen bonds between them and starch, reducing the interchain space of the polymer (Saberi et al., 2017). Zhao and Saldaña (2019) suggested even the occurrence of ester linkages between hydroxyl groups of starch and carboxyl groups of gallic acid (Zhao \& Saldaña, 2019) to explain why the WVP of the starch films produced in their study was decreased by gallic acid.

The phenolics strongly increased the UV absorption of the films, corroborating other studies (Eça, Machado, Hubinger, \& Menegalli, 2015; Li, Sirviö, Haapala, Khakalo, \& Liimatainen, 2019; Limpisophon \& Schleining, 2017; Piñeros-Hernandez et al., 2017), which is ascribed to the conjugated double bonds in phenolic rings (Ray, Gupta, \& Ghosh, 2013) and the phenolic hydroxyl groups that enhance the $n \rightarrow \pi *$ absorption in UV range (Ge et al., 2018). The importance of UV barrier in food packaging and coating is related to a number of adverse effects of UV light (200-400 nm) on foods, including the promotion of oxidation of lipids and some other nutrients.

On the other hand, MKPE and (to a lower extent) MKF impaired the film transparency to visible light. Indeed, both the fat and the phenolics made the films translucent, and the films with phenolics also developed a light brownish color, as also observed for films with tannins (Li et al., 2019) and tea polyphenols (Lei et al., 2019; Wu et al., 2019). Although such a loss in transparency is usually considered as a limitation to most food packaging applications, some applications may not be impaired by it. Edible nuts, for example, being highly oxidizable, could be benefitted 

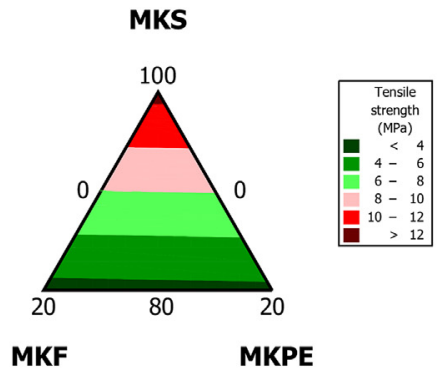
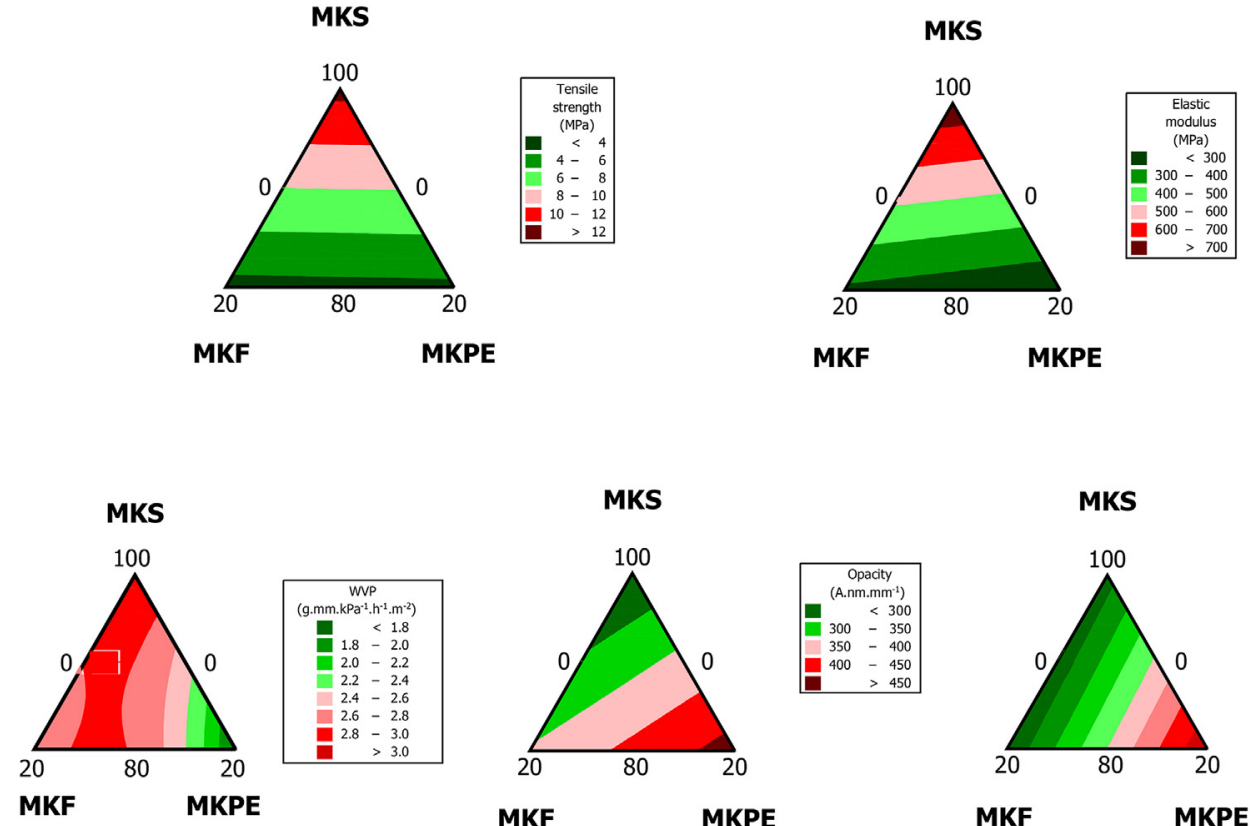
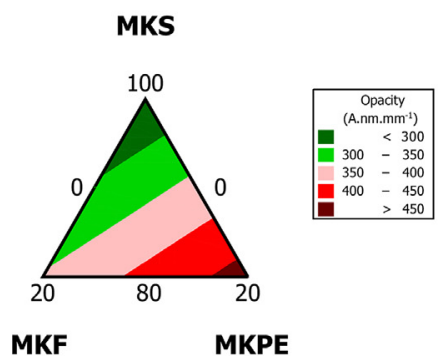

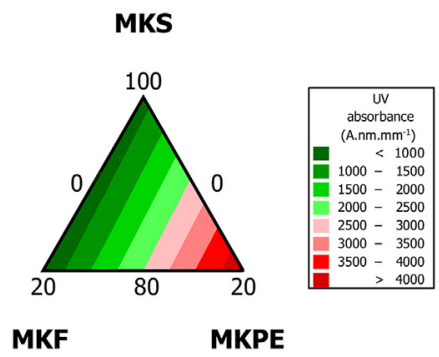

Fig. 3. Contour plots of the physical properties of films.

from the antioxidant properties of MKPE-containing films or coatings, and (since most of them are already brownish) probably would not have their acceptance impaired by the translucency or brownish colors of the materials.

Although the model for antioxidant activity was not significant, it may be drawn from the average responses that the presence of MKPE, even at contents as low as $3.33 \%$ (films \#8 and \#9), provided the films with more than $90 \%$ inhibition of DPPH, representing an increase in antioxidant activity of at least 35 times when compared to the MKS film (\#1). Moreover, this DPPH inhibition was higher than those reported for other films with antioxidant components such as licorice residue extract (Han, Yu, \& Wang, 2018), epigallocatechin gallate nanocapsules (Liang et al., 2017), tea extracts (Lei et al., 2019; Wu et al., 2019; Yang, Lee, Won, \& Song, 2016), or even mango peel extracts and mango kernel extracts (Adilah et al., 2018a, 2018b).

Taking just the DPPH inhibition into account, the MKPE contents in this study seem to be in excess. On the other hand, even the higher MKPE contents may be useful for applications that require a high UV absorption capacity and a low WVP. Moreover, although this is not the focus of this study, when used in edible coatings, the phenolics may

Table 3

Physical properties of films and regression coefficients (in pseudo-components).

\begin{tabular}{|c|c|c|c|c|c|c|c|}
\hline \multirow[t]{2}{*}{ Films } & \multicolumn{7}{|c|}{ Average responses } \\
\hline & $\sigma$ & $\varepsilon$ & $\mathrm{E}$ & WVP & OPA & UVAB & AA \\
\hline 1 & $14.46 \mathrm{a}$ & $15.93 \mathrm{bc}$ & $839.2 \mathrm{a}$ & $3.012 \mathrm{a}$ & 248.7 e & $381.8 \mathrm{~d}$ & $2.54 \mathrm{c}$ \\
\hline 2 & 4.04 ef & $9.29 \mathrm{c}$ & 308.6 def & $2.592 \mathrm{ab}$ & $371.8 \mathrm{bc}$ & $826.7 \mathrm{~cd}$ & $3.79 \mathrm{c}$ \\
\hline 3 & 4.00 ef & 48.57 a & 252.5 ef & $1.780 \mathrm{c}$ & $443.4 \mathrm{a}$ & 3849.9 a & $92.08 \mathrm{~b}$ \\
\hline 4 & $4.96 \mathrm{de}$ & 49.37 a & $390.0 \mathrm{~cd}$ & $2.872 \mathrm{a}$ & $272.9 \mathrm{de}$ & $459.3 \mathrm{~d}$ & $4.73 \mathrm{c}$ \\
\hline 5 & $5.77 \mathrm{~d}$ & $45.61 \mathrm{a}$ & $361.0 \mathrm{cdef}$ & $2.600 \mathrm{ab}$ & $341.6 \mathrm{bc}$ & $3277.4 \mathrm{ab}$ & 97.99 a \\
\hline 6 & $3.66 \mathrm{f}$ & $56.61 \mathrm{a}$ & $246.2 \mathrm{f}$ & $2.863 \mathrm{a}$ & $409.4 \mathrm{ab}$ & $2890.5 \mathrm{~b}$ & $95.15 \mathrm{ab}$ \\
\hline 7 & $6.91 \mathrm{c}$ & $42.19 \mathrm{a}$ & 430.9 c & $2.882 \mathrm{a}$ & $400.0 \mathrm{ab}$ & $2836.4 \mathrm{~b}$ & $97.22 \mathrm{a}$ \\
\hline 8 & $10.10 \mathrm{~b}$ & $26.87 \mathrm{~b}$ & $657.5 \mathrm{~b}$ & $2.716 \mathrm{ab}$ & $342.1 \mathrm{bc}$ & $1405.5 \mathrm{c}$ & $96.69 \mathrm{ab}$ \\
\hline 9 & $5.76 \mathrm{~d}$ & $17.15 \mathrm{bc}$ & 389.8 cde & $2.732 \mathrm{a}$ & $320.6 \mathrm{~cd}$ & $320.6 \mathrm{~d}$ & $94.92 \mathrm{ab}$ \\
\hline 10 & $5.61 \mathrm{~d}$ & 55.93 a & 322.0 cdef & $2.195 \mathrm{bc}$ & $459.3 \mathrm{a}$ & 2993.7 b & $96.51 \mathrm{ab}$ \\
\hline \multirow[t]{2}{*}{ Terms } & \multicolumn{7}{|c|}{ Coefficients } \\
\hline & $\sigma$ & $\varepsilon$ & $\mathbf{E}$ & WVP & OPA & UVAB & AA \\
\hline$\beta_{1}$ & 12.53 & 15.97 & 763.8 & 3.00 & 257.0 & 771.6 & 8.11 \\
\hline$\beta_{2}$ & 3.43 & 6.28 & 282.6 & 2.60 & 354.5 & 577.5 & 9.02 \\
\hline$\beta_{3}$ & 3.63 & 52.91 & 212.9 & 1.74 & 471.4 & 4423.4 & 81.24 \\
\hline$\beta_{12}$ & - & 99.34 & - & 0.02 & - & - & 88.24 \\
\hline$\beta_{13}$ & - & 20.45 & - & 0.46 & - & - & 252.55 \\
\hline$\beta_{23}$ & - & 71.63 & - & 2.39 & - & - & 238.02 \\
\hline $\mathrm{R}^{2}(\%$, adj) & 74.48 & 39.19 & 80.64 & 80.29 & 74.33 & 77.81 & 58.48 \\
\hline $\mathrm{F}$ & 14.13 & 2.16 & 19.75 & 8.33 & 14.03 & 16.78 & 3.54 \\
\hline $\mathrm{p}$ & $<0.01$ & 0.24 & $<0.01$ & 0.03 & $<0.01$ & $<0.01$ & 0.12 \\
\hline
\end{tabular}

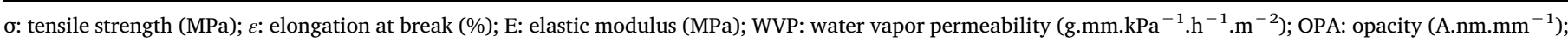

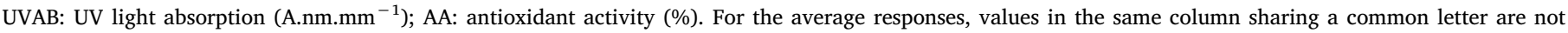

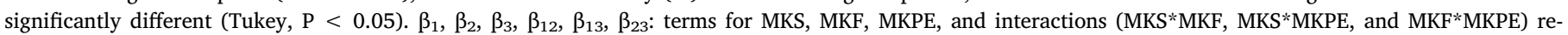
spectively (as pseudo-components). 

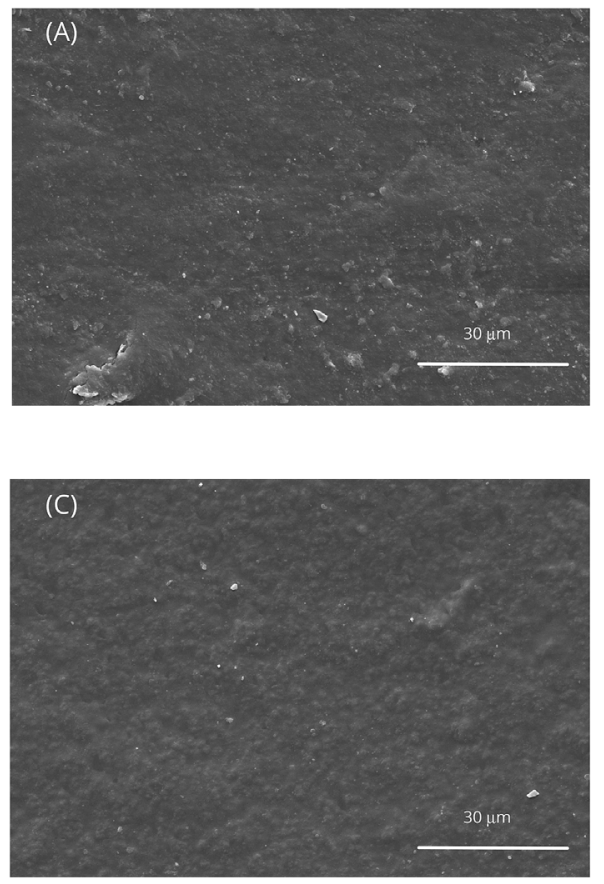

Fig. 4. SEM micrographs of mango kernel starch films: (A) Film \#1: 100\% MKS; $80 \%$ MKS, $10 \%$ MKF, 10\% MKPE.

have a role on consumers health, as reviewed by Shahidi and Ambigaipalan (2015), imparting the coatings (and thus the coated foods) with bioactive properties.

Thus, the phenolics provided the films with the expected active effects (that is to say, primary antioxidant and UV absorption effects). On the other hand, the main expected advantage of MKF (i.e., decreasing the WVP) was not as remarkable as the WVP-drecreasing effect of the phenolics. So, antioxidant films with a reasonable barrier to water vapor may be produced from MKS and MKPE, even without MKF. No ideal MKPE content has been defined, since higher phenolic contents result in better barrier and active properties at the expense of tensile properties and transparency. The most suitable formulation should be defined according to the needs for each application, considering the pros and cons of each MKPE content.

The FTIR spectra of the mango kernel components and films are presented at Fig. 5. The spectra of the films were similar to that of MKS, with bands at the $1100-1150 \mathrm{~cm}^{-1}$ range ascribed to $\mathrm{CO}, \mathrm{CC}$ and $\mathrm{COH}$ stretching, and $\mathrm{COH}$ bending bands at the $900-1100 \mathrm{~cm}^{-1}$ range (Warren, Gidley, \& Flanagan, 2016). Some bands in films \#2 and \#6 are ascribed to MKF, such as those for asymmetrical and symmetrical stretching of $-\mathrm{CH}_{2}$ around $2920 \mathrm{~cm}^{-1}$ and $2850 \mathrm{~cm}^{-1}$ respectively (Gallart-Sirvent et al., 2017), and another at $1473 \mathrm{~cm}^{-1}$ due to $\mathrm{C}-\mathrm{H}$ bending of $\mathrm{CH}_{2}$ (Mazurek, Szostak, \& Kita, 2016). The carbonyl stretch band at $1730 \mathrm{~cm}^{-1}$ (Cai et al., 2015) for MKF shifted to higher wavenumbers in films, suggesting MKF interactions with other components. Most MKPE bands presented low intensity when in the films (\#3 and \#6), such as the one at $1708 \mathrm{~cm}^{-1}$ due to $\mathrm{C}=\mathrm{O}$ and/or aromatic $\mathrm{C}=\mathrm{C}$ stretching (Jindo et al., 2016), the $\mathrm{G}$ band at $1603 \mathrm{~cm}^{-1}$ ascribed to bond stretching of $\mathrm{sp}^{2}$ atoms in aromatic rings (Schwan, Ultrich, Batori, \& Ehrhardt, 1996; Yu et al., 2016), the phenolic ring in-plane deformation band at $1533 \mathrm{~cm}^{-1}$ (Ricci et al., 2016), and the C-O stretch band at $1199 \mathrm{~cm}-1$ (Grasel, Ferrão, \& Wolf, 2016).

The air surface of films \#1, \#3 and \#6 were relatively smooth and without cracks (Fig. 4), whereas film \#2 (with the highest MKF content) presented some discontinuities, which may result from coalescence of fat droplets due to the high fat content and/or to brittleness promoted by the rigidity of the solid SFAs. The black spots in film \#2, also found by Kowalczyk et al. (2016) in films containing candelilla wax, are also
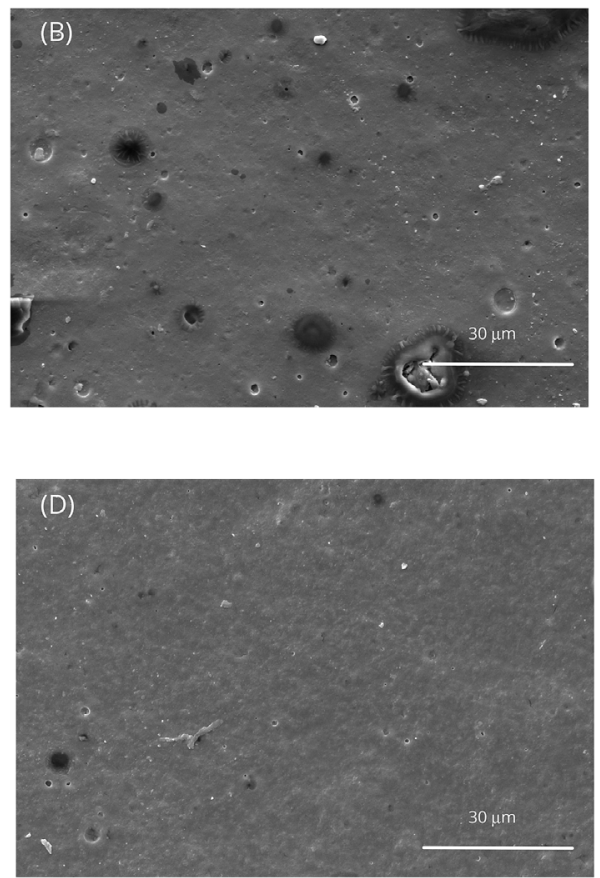

; (B) film \#2: 80\% MKS, 20\% MKF; (C) film \#3: 80\% MKS, 20\% MKPE; (D) film \#6:

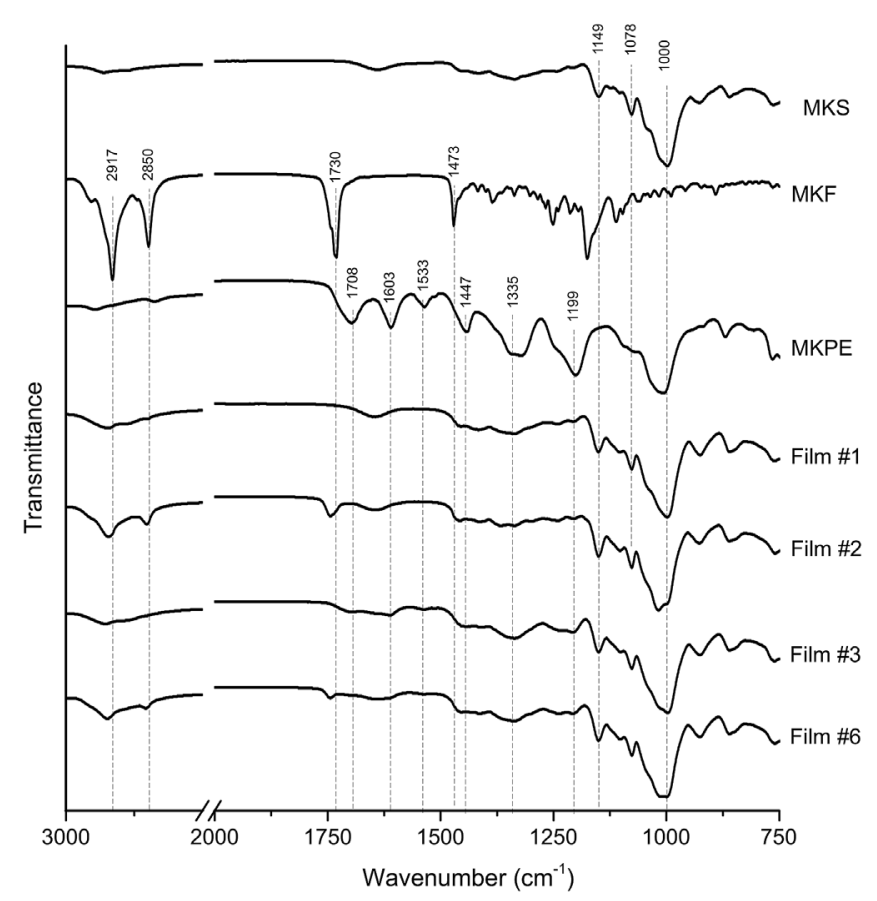

Fig. 5. FTIR spectra of mango kernel components and resulting films. Film \#1: 100\% MKS; film \#2: 80\% MKS, 20\% MKF; film \#3: 80\% MKS, 20\% MKPE; film \#6: $80 \%$ MKS, 10\% MKF, 10\% MKPE.

ascribed to lipid globules. Those discontinuities had a role on the sharp decrease of elongation of film \#2 when compared to films with lower MKF contents.

\section{Conclusions}

This study was focused on obtaining films with a double active role (primary antioxidant and UV absorber) from mango kernel starch (MKS) added with two other mango kernel components - namely, fat 
(MKF) and phenolics (MKPE). Films with remarkable primary antioxidant activity, UV absorbing capacity, and good barrier properties have been produced from MKS and MKPE, even without MKF. Ideal formulations are to be defined for each intended application, since higher phenolic contents result in better active properties and barrier to water vapor, but impair tensile properties and transparency. The active films are particularly interesting for applications as bags, pouches or coatings to oxidizable foods such as nuts, meat derivatives, and cheeses. Future studies are required to explore those applications. Anyway, edible nuts are particularly expected to be benefitted from coatings based on the mango kernel film formulations presented in this study, since their main deteriorative changes are related to oxidation. Moreover, the light brownish colors provided by the presence of phenolics may not limit the visual acceptance of nuts, most of which are brownish by themselves.

\section{Acknowledgements}

The authors gratefully acknowledge the financial support of the Brazilian Agricultural Research Corporation (Embrapa, 02.14.04.002.00.00). They also thank the Central Analítica-UFC/CTINFRA/MCTI-SIS-NANO/Pró-Equipamentos CAPES for the use of their facilities for the SEM analyses. We thank the Coordination for the Improvement of Higher Education Personnel (CAPES, 1586783) and Fundação Cearense de Apoio ao Desenvolvimento Científico e Tecnológico (FUNCAP, BMD-0008-00640.01.11/15) for the scholarships granted to P.E.F. Melo and A.P.M. Silva respectively. The authors also acknowledge the National Council for Scientific and Technological Development (CNPq) for the Research Productivity Fellowships granted to E.S. Brito and H.M.C. Azeredo (302770/2015-1 and 302381/2016-3, 2016 respectively).

\section{References}

Adilah, Z A. M., Jamilah, B. \& Hanani, Z A. N. (2018a). Functional and antioxidant properties of protein-based films incorporated with mango kernel extract for active packaging. Food Hydrocolloids, 74, 207-218.

Adilah, Z. A. M., Jamilah, B., Noranizan, M. A., \& Hanani, Z. A. N. (2018b). Utilization of mango peel extracts on the biodegradable films for active packaging. Food Packaging and Shelf Life, 16, 1-7.

Alkan, D., \& Yemenicioğlu, A. (2016). Potential application of natural phenolic antimicrobials and edible film technology against bacterial plant pathogens. Food Hydrocolloids, 55, 1-10.

Arora, A., Banerjee, J., Vijayaraghavan, R., MacFarlane, D., \& Patti, A. F. (2018). Process design and techno-economic analysis of an integrated mango processing waste biorefinery. Industrial Crops and Products, 116, 24-34.

ASTM D882-12 (2012). Standard test method for tensile properties of thin plastic sheeting. West Conshohocken: ASTM International.

ASTM E96/E96M-16 (2016). Standard test methods for water vapor transmission of materials. West Conshohocken: ASTM International.

Banerjee, J., Singh, R., Vijayaraghavan, R., MacFarlane, D., Patti, A. F., \& Arora, A. (2018). A hydrocolloid based biorefinery approach to the valorisation of mango peel waste. Food Hydrocolloids, 77, 142-151.

Barbosa-Pereira, L., Aurrekoetxea, G. P., Angulo, I., Paseiro-Losada, P., \& Cruz, J. M. (2014). Development of new active packaging films coated with natural phenolic compounds to improve the oxidative stability of beef. Meat Science, 97, 249-254.

Barreto, J. C., Trevisan, M. T. S., Hull, W. E., Erben, G., Brito, E. S., Pfundstein, B., et al. (2008). Characterization and quantitation of polyphenolic compounds in bark, kernel, leaves, and peel of mango (Mangifera indica L.). Journal of Agricultural and Food Chemistry, 56, 5599-5610.

Byun, Y., Kim, Y. T., \& Whiteside, S. (2010). Characterization of an antioxidant polylactic acid (PLA) film prepared with $\alpha$-tocopherol, BHT and polyethylene glycol using film cast extruder. Journal of Food Engineering, 100, 239-244.

Cai, Y., Sun, G., Liu, M., Zhang, J., Wang, Q., \& Wei, Q. (2015). Fabrication and characterization of capric-lauric-palmitic acid/electrospun SiO2 nanofibers composite as form-stable phase change material for thermal energy storage/retrieval. Solar Energy, 118, 87-95.

Choi, I., Lee, S. E., Chang, Y., Lacroix, M., \& Han, J. (2018). Effect of oxidized phenolic compounds on cross-linking and properties of biodegradable active packaging film composed of turmeric and gelatin. Lebensmittel-Wissenschaft und -Technologie, 93, 427-433.

Dai, L., Qiu, C., Xiong, L., \& Sun, Q. (2015). Characterisation of corn starch-based films reinforced with taro starch nanoparticles. Food Chemistry, 174, 82-88.

Dorta, E., González, M., Lobo, M. G., Sánchez-Moreno, C., \& de Ancos, B. (2014). Screening of phenolic compounds in by-product extracts from mangoes (Mangifera indica L.) by HPLC-ESI-QTOF-MS and multivariate analysis for use as a food ingredient. Food Research International, 57, 51-60.

Dou, L., Li, B., Zhang, K., Chu, X., \& Hou, H. (2018). Physical properties and antioxidant activity of gelatin-sodium alginate edible films with tea polyphenols. International Journal of Biological Macromolecules, 118B, 1377-1383.

Esposito, D., \& Antonietti, M. (2015). Redefining biorefinery: The search for unconventional building blocks for materials. Chemical Society Reviews, 44, 5821-5835.

Eça, K. S., Machado, M. T. C., Hubinger, M. D., \& Menegalli, F. C. (2015). Development of active films from pectin and fruit extracts: Light protection, antioxidant capacity, and compounds stability. Journal of Food Science, 80, C2389-C2396.

Fabra, M. J., Falcó, I., Randazzo, W., Sánchez, G., \& López-Rubio, A. (2018). Antiviral and antioxidant properties of active alginate edible films containing phenolic extracts. Food Hydrocolloids, 81, 96-103.

Fernández, A., Cebrián, V., \& Maté (2007). Effect of the unsaturation degree and concentration of fatty acids on the properties of WPI-based edible films. European Food Research and Technology, 224, 415-420.

Gallart-Sirvent, P., Martín, M., Villorbina, G., Baicells, M., Solé, A., Barrenche, C., et al. (2017). Fatty acid eutectic mixtures and derivatives from non-edible animal fat as phase change materials. RSC Advances, 7, 24133-24139.

Ge, L., Zhu, M., Li, X., Xu, Y., Ma, X., Shi, R., et al. (2018). Development of active rosmarinic acid-gelatin biodegradable films with antioxidant and long-term antibacterial activities. Food Hydrocolloids, 83, 308-316.

Gómez-Caravaca, A. M., López-Cobo, A., Verardo, V., Segura-Carretero, A., \& Fernández-Gutiérrez, A. (2016). HPLC-DAD-q-TOF-MS as a powerful platform for the determination of phenolic and other polar compounds in the edible part of mango and its by-products (peel, seed, and seed husk). Electrophoresis, 37, 1072-1084.

Grasel, F. S., Ferrão, M. F., \& Wolf, C. R. (2016). Development of methodology for identification the nature of the polyphenolic extracts by FTIR associated with multivariate analysis. Spectrochimica Acta Part A: Molecular and Biomolecular Spectroscopy, 153, 94-101.

GTZ (Deutsche Gesellschaft für Technische Zusammenarbeit) (1992). Manual de exportacion: Frutas tropicales y hortalizasEschborn 34p.

Han, Y., Yu, M., \& Wang, L. (2018). Preparation and characterization of antioxidant soy protein isolate films incorporating licorice residue extract. Food Hydrocolloids, 75, $13-21$.

Haq, M. A., Alam, M. J., \& Hasnain, A. (2013). Gum Cordia: A novel edible coating to increase the shelf life of Chilgoza (Pinus gerardiana). Lebensmittel-Wissenschaft und -Technologie- Food Science and Technology, 50, 306-311.

Hartman, L., \& Lago, R. C. A. (1973). Rapid preparation of fatty acid methyl esters from lipids. Laboratory Practice, 22, 475-476.

IAL - Instituto Adolfo Lutz (2008). Métodos físico-químicos para análise de alimentos. Available at: http://www.ial.sp.gov.br/resources/editorinplace/ial/2016_3_19/ analisedealimentosial_2008.pdf.

Irissin-Mangata, J., Bauduin, G., Boutevin, B., \& Gontard, N. (2001). New plasticizers for wheat gluten films. European Polymer Journal, 37, 1533-1541.

ISO 6647-1 (2015). Rice - determination of amylose content - Part 1. Reference method. Geneva: International Standardization Organization.

Jahurul, M. H. A., Jing, Y. W., Foong, C. Y., Shaarani, S. M., Zaidul, I. S. M., Jinap, S., et al. (2017). Effect of accelerated storage on chemical compositions of mango seed fat and palm oil mid-fraction blends as cocoa butter replacers. LWT Food Science \& Technology, 84, 551-554.

Jahurul, M. H. A., Zaidul, I. S. M., Ghafoor, K., Al-Juhaimi, F. Y., Nyam, K. L., Norulaini, N. A. N., et al. (2015a). Mango (Mangifera indica L.) by-products and their valuable components: A review. Food Chemistry, 183, 173-180.

Jahurul, M. H. A., Zaidul, I. S. M., Norulaini, N. A. N., Sahena, F., Kamaruzzaman, B. Y., Ghafoor, K., et al. (2015b). Cocoa butter replacers from blends of mango seed fat extracted by supercritical carbon dioxide and palm stearin. Food Research International, 65, 401-406.

Jaramillo, C. M., Gutiérrez, T. J., Goyanes, S., Bernal, C., \& Famá, L. (2016) Biodegradability and plasticizing effect of yerba mate extract on cassava starch edible films. Carbohydrate Polymers, 151, 150-159.

Jindo, K., Sonoki, T., Matsumoto, K., Canellas, L., Roig, A., \& Sanchez-Monedero, M. A. (2016). Influence of biochar addition on the humic substances of composting manures. Waste Management, 49, 545-552.

Kang, H. J., Kim, S. J., You, Y. S., Lacroix, M., \& Han, J. (2013). Inhibitory effect of soy protein coating formulations on walnut (Juglans regia L.) kernels against lipid oxidation. Lebensmittel-Wissenschaft und-Technologie- Food Science and Technology, 51, 393-396.

Kaur, M., Singh, N., Sandhu, K. S., \& Guraya, H. (2004). Physicochemical, morphological, thermal and rheological properties of starches separated from kernels of some Indian mango cultivars (Mangifera indica L.). Food Chemistry, 85, 131-140.

Kowalczyk, D., Gustaw, W., Zięba, E., Lisiecki, S., Stadnik, J., \& Baraniak, B. (2016). Microstructure and functional properties of sorbitol-plasticized pea protein isolate emulsion films: Effect of lipid type and concentration. Food Hydrocolloids, 60, 353-363.

Lei, Y., Wu, H., Jiao, C., Jiang, Y., Liu, R., Xiao, D., et al. (2019). Investigation of the structural and physical properties, antioxidant and antimicrobial activity of pectinkonjac glucomannan composite edible films incorporated with tea polyphenol. Food Hydrocolloids, 94, 128-135.

Liang, J., Yan, H., Zhang, J., Dai, W., Gao, X., Zhou, Y., et al. (2017). Preparation and characterization of antioxidant edible chitosan films incorporated with epigallocatechin gallate nanocapsules. Carbohydrate Polymers, 171, 300-306.

Li, J., Kuang, G., Chen, X., \& Zeng, R. (2016). Identification of chemical composition of leaves and flowers from Paeonia rockii by UHPLC-Q-Exactive Orbitrap HRMS. Molecules, 21, 21-27.

Limpisophon, K., \& Schleining, G. (2017). Use of gallic acid to enhance the antioxidant 
and mechanical properties of active fish gelatin film. Journal of Food Science, 82, 80-89.

Li, P., Sirviö, J. A., Haapala, A., Khakalo, A., \& Liimatainen, H. (2019). Anti-oxidative and UV-absorbing biohybrid film of cellulose nanofibrils and tannin extract. Food Hydrocolloids, 92, 208-217.

Matharu, A. S., Houghton, J. A., Lucas-Torres, C., \& Moreno, A. (2016). Acid-free microwave-assisted hydrothermal extraction of pectin and porous cellulose from mango peel waste - towards a zero waste mango biorefinery. Green Chemistry, 18, 5280-5287.

Mazurek, S., Szostak, R., \& Kita, A. (2016). Application of infrared reflection and Raman spectroscopy for quantitative determination of fat in potato chips. Journal of Molecular Structure, 1126, 213-218.

Mellinas, C., Valdés, A., Ramos, M., Burgos, N., Garrigós, M. C., \& Jiménez, A. (2015). Active edible films: Current state and future trends. Journal of Applied Polymer Science, $133,42631$.

Nawab, A., Alam, F., Haq, M. A., \& Hasnain, A. (2016). Biodegradable film from mango kernel starch: Effect of plasticizers on physical, barrier, and mechanical properties. Starch - Stärke, 68, 919-928.

Nawab, A., Alam, F., Haq, M. A., Lufti, Z., \& Hasnain, A. (2017). Mango kernel starch-gum composite films: Physical, mechanical and barrier properties. International Journal of Biological Macromolecules, 98, 869-876.

Oliveira, A. V., Silva, A. P. M., Barros, M. O., Souza Filho, M. S. M., Rosa, M. F., \& Azeredo, H. M. C. (2018). Nanocomposite films from mango kernel or corn starch with starch nanocrystals. Starch - Stärke, 70, 1800028.

Pérez-Gallardo, A., García-Almendárez, B., Barbosa-Cánovas, G., Pimentel-González, D., Reyes-González, L. R., \& Regalado, C. (2015). Effect of starch-beeswax coatings on quality parameters of blackberries (Rubus spp.). Journal of Food Science \& Technology, $52,5601-5610$

Piñeros-Hernandez, D., Medina-Jaramillo, C., López-Córdoba, A., \& Goyanes, S. (2017). Edible cassava starch films carrying rosemary antioxidant extracts for potential use as active food packaging. Food Hydrocolloids, 63, 488-495.

Plant-O-Gram (2015). Mango tree Tommy Atkins variety grafted. Available at: https:// plantogram.com/product/mango_tommy_atkins/.

Ray, A., Gupta, S. D., \& Ghosh, S. (2013). Evaluation of anti-oxidative activity and UV absorption potential of the extracts of Aloe vera L. gel from different growth periods of plants. Industrial Crops and Products, 49, 712-719.

Rocca-Smith, J. R., Marcuzzo, E., Karbowiak, T., Centa, J., Giacometti, M., Scapin, F., et al. (2016). Effect of lipid incorporation on functional properties of wheat gluten based edible films. Journal of Cereal Science, 69, 275-282.

Rodrigues, D. C., Caceres, C. A., Ribeiro, H. L., Abreu, R. F. A., Cunha, A. P., \& Azeredo, H. M. C. (2014). Influence of cassava starch and carnauba wax on physical properties of cashew tree gum-based films. Food Hydrocolloids, 38, 147-151.

Sabaghi, M., Maghsoudlou, Y., Khomeiri, M., \& Ziaiifar, A. M. (2015). Active edible coating from chitosan incorporating green tea extract as an antioxidant and antifungal on fresh walnut kernel. Postharvest Biology and Technology, 110, 224-228.

Saberi, B., Vuong, Q. V., Chockchaisawasdee, S., Golding, J. B., Scarlett, C. J., \& Stathopoulos, C. E. (2017). Physical, barrier, and antioxidant properties of pea starchguar gum biocomposite edible films by incorporation of natural plant extracts. Food and Bioprocess Technology, 10, 2240-2250.

Sartori, T., \& Menegalli, F. C. (2016). Development and characterization of unripe banana starch films incorporated with solid lipid microparticles containing ascorbic acid. Food Hydrocolloids, 55, 210-219.
Schwan, J., Ultrich, S., Batori, V., \& Ehrhardt, H. (1996). Raman Spectroscopy on amorphous carbon films. Journal of Applied Physics, 80, 440-447.

Shahidi, F., \& Ambigaipalan, P. (2015). Phenolics and polyphenolics in foods, beverages and spices: Antioxidant activity and health effects - a review. Journal of Functional Foods, 18, 820-897.

Sifentes-Nieves, I., Hernández-Hernández, E., Neira-Velázquez, G., Morales-Sánchez, E., Mendez-Montealvo, G., \& Velazquez, G. (2019). Hexamethyldisiloxane cold plasma treatment and amylose content determine the structural, barrier and mechanical properties of starch-based films. International Journal of Biological Macromolecules, 124, 651-658.

Silva, A. P. M., Oliveira, A. V., Pontes, S. M. A., Pereira, A. L. S., Souza Filho, M. S. M., Rosa, M. F., et al. (2019). Mango kernel starch films as affected by starch nanocrystals and cellulose nanocrystals. Carbohydrate Polymers, 211, 209-216.

Singleton, V. L., \& Rossi, J. A. (1965). Colorimetry of total phenolics with phosphomolybdic-phosphotungstic acid reagents. American Journal of Enology and Viticulture, 16, 144-158.

Sonwai, S., Kaphueakngam, P., \& Flood, A. (2014). Blending of mango kernel fat and palm oil mid-fraction to obtain cocoa butter equivalent. Journal of Food Science \& Technology, 51, 2357-2369.

Statista (2018). Mango production worldwide from 2000 to 2016. (in million metric tons). Available at: https://www.statista.com/statistics/577951/world-mangoproduction/.

Sumner, L. W., Amberg, A., Barrett, D., Beale, M. H., Beger, R., Daykin, C. A., et al. (2007). Proposed minimum reporting standards for chemical analysis. Metabolomics, $3,211-221$.

Tongnuanchan, P., Benjakul, S., Prodpran, T., \& Nilsuwan, K. (2015). Emulsion film based on fish skin gelatin and palm oil: Physical, structural and thermal properties. Food Hydrocolloids, 48, 248-259.

UNCTAD - United Nations Conference on Trade and Development (2016). Mango - an INFOCOMM commodity profile. Available at http://unctad.org/en/ PublicationsLibrary/INFOCOMM_cp07_Mango_en.pdf.

Wambura, P., Yang, W., \& Mwakatage, N. R. (2011). Effects of sonication and edible coating containing rosemary and tea extracts on reduction of peanut lipid oxidative rancidity. Food and Bioprocess Technology, 4, 107-115.

Warren, F. J., Gidley, M. J., \& Flanagan, B. M. (2016). Infrared spectroscopy as a tool to characterise starch ordered structure-a joint FTIR-ATR, NMR, XRD and DSC study. Carbohydrate Polymers, 139, 35-42.

Wu, H., Lei, Y., Zhu, R., Zhao, M., Lu, J., Xiao, D., et al. (2019). Preparation and characterization of bioactive edible packaging films based on pomelo peel flours incorporating tea polyphenol. Food Hydrocolloids, 90, 41-49.

Xiao, J., Wang, W., Wang, K., Liu, Y., Liu, A., Zhang, S., et al. (2016). Impact of melting point of palm oil on mechanical and water barrier properties of gelatin-palm oil emulsion film. Food Hydrocolloids, 60, 243-251.

Yang, H. J., Lee, J. H., Won, M., \& Song, K. B. (2016). Antioxidant activities of distiller dried grains with solubles as protein films containing tea extracts and their application in the packaging of pork meat. Food Chemistry, 196, 174-179.

Yu, S., Wang, X., Ai, Y., Tan, X., Hayat, T., Hu, W., et al. (2016). Experimental and theoretical studies on competitive adsorption of aromatic compounds on reduced graphene oxides. Journal of Materials Chemistry, 4, 5654-5662.

Zhao, Y., \& Saldaña, M. D. A. (2019). Use of potato by-products and gallic acid for development of bioactive film packaging by subcritical water technology. The Journal of Supercritical Fluids, 143, 97-106. 